\title{
Pengintegrasian LPD Sebagai Sumber Belajar Dalam Pembelajaran IPS di SMP Negeri 4 Singaraja
}

\author{
Made Roby Pratama Purna ${ }^{1 *}$, I Wayan Kertih ${ }^{1}$, Anantawikrama Tungga Atmadja ${ }^{1}$ \\ 1Universitas Pendidikan Ganesha, Indonesia \\ *e-mail: pratamapurna720@gmail.com
}

Article history: Received 08 July 2021; Accepted 14 July 2021; Available online 31 August 2021

\begin{abstract}
Abstrak
Penelitian ini bertujuan untuk mengetahui sejarah LPD di Desa Sambangan, mengetahui bagaimana mengintegrasikan dan melakukan inovasi pembelajaran, mengetahui nilai karakter, mengetahui menyusun RPP pada kurikulum 2013, mengetahui persepsi siswa dan guru di SMP Negeri 4 Singaraja terhadap pengintegrasian LPD Sambangan ke dalam pembelajaran IPS. Metode yang digunakan dalam penelitian adalah penelitian kualitatif. Data diperoleh melalui wawancara, observasi dan studi dokumen. Hasil penelitian ini menunjukkan LPD Sambangan didirikan berdasarkan SK Gubernur Nomor 144 Tahun 1992. Inovasi pembelajaran sangat penting dilakukan. Nilai karakter yang terkandung Religius, Disiplin, Gotong Royong, Kejujuran, Tanggung Jawab, dan Kerja Keras. Selain nilai karakter tersebut terdapat pula nilai kearifan lokal seperti Taksu, Tri Hita Karana, Menyama Braya, dan Jengah. RPP mengacu pada Permendikbud Republik Indonesia Nomor 14 Tahun 2019 tentang penyederhanaan RPP. Persepsi guru dan siswa berbanding lurus dengan apa yang dituangkan peneliti yaitu mereka setuju dan mendukung penyisipan bahan ajar LPD Sambangan ke dalam pembelajaran IPS.
\end{abstract}

\begin{abstract}
This study aims to find out the history of LPD in Sambangan Village, to know how to integrate and innovate learning, to know character values, to know how to compose lesson plans in the 2013 curriculum, to know the perceptions of students and teachers at SMP Negeri 4 Singaraja towards integrating Sambangan LPD into social studies learning. The method used in this research is qualitative research. Data were obtained through interviews, observation, and document studies. This study indicates that the Sambangan LPD was established based on the Governor's Decree Number 144 of 1992. Learning innovation is very important to do. The character values contained are Religious, Discipline, Mutual Cooperation, Honesty, Responsibility, and Hard Work. In addition to these character values, there are also local wisdom values such as Taksu, Tri Hita Karana, Menyama Braya, and Jengah. The RPP refers to the Minister of Education and Culture of the Republic of Indonesia Number 14 of 2019 concerning the simplification of the RPP. The perceptions of teachers and students are directly proportional to what the researchers stated. They agree and support the insertion of Sambangan LPD teaching materials into social studies learning.
\end{abstract}

Kata Kunci:

LPD; Nilai Karakter; Integrasi;

Pembelajaran; IPS

Keywords:

LPD; Character Values; Integration; Learning; Social Studies 


\section{Pendahuluan}

Pendidikan IPS merupakan salah satu mata pelajaran yang dianggap penting untuk menumbuhkan jiwa sosial peserta didik sebagai bagian dari masyarakat. Namun, kelemahan pendidikan IPS di Indonesia masih sangat terlihat dan perlu adanya perbaikan. Al Muchtar (2001) menyatakan kelemahan yang ada pada pendidikan IPS lebih menonjol dibandingkan keunggulannya, sehingga berimplikasi pada rendahnya mutu pendidikan IPS baik dari segi proses maupun hasilnya.

Permasalahan mendasar pendidikan IPS di sekolah juga diungkapkan oleh Solihatin (2012), yaitu (1) masih menggunakan model pembelajaran konvensional, (2) tujuan pendidikan IPS sulit dicapai, (3) siswa menjadi objek pembelajaran, (4) teacher centre, (5) kurang mendorong dan merangsang siswa untuk mengembangkan potensi inkuiri, (6) materi IPS masih bersifat hafalan, (7) evaluasi hanya sebatas pada kognitif, (8) prestasi siswa tidak dioptimalkan, dan (9) pola interaksi dalam pembelajaran masih bersifat satu arah. Kelemahan pendidikan IPS yang berkaitan dengan pembahasan ini adalah bersumber dari Susanto (2014), Pendidikan IPS dikatakan tidak bisa memberikan makna dari apa yang telah dipelajari, sehingga dianggap hanya untuk kepentingan sesaat tanpa ada manfaat praktis dalam kehidupan sehari-hari di masyarakat dan belum menjadikan nilai sosial budaya yang dikembangkan di lingkungan masyarakat menjadi sumber belajar siswa.

Mengingat persoalan-persoalan yang terjadi sangat krusial dalam peroses tersebut, sehingga dibutuhkan upaya dan mesinergitaskan yang cerdas untuk menjawab semua bentuk persoalan yang ada terutama pengembangan pendidikan karakter dalam pendidikan IPS. Pemanfaatan lingkungan sekitar sekolah dan siswa sebagai sumber utama materi pengayaan dalam pembelajaran IPS merupakan sebuah kewajiban, mengingat laboratorium IPS adalah masyarakat, lingkungan, dan interaksinya (Lasmawan, 2010). Bertalian dengan itu, maka salah satu yang dianggap layak untuk dijadikan sumber belajar khususnya pendidikan karakter adalah sistem dan interaksi.

Lembaga ekonomi merupakan salah satu sumber belajar IPS yang berkaitan dengan sistem dan interaksi dalam kehidupan masyarakat. Lembaga ekonomi dikategorikan lembaga ekonomi karena lembaga ini merupakan bagian dari lembaga sosial yang mengatur tata hubungan antar manusia dalam pemenuhan kebutuhan hidup sehari-hari. Lembaga ekonomi lahir sebagai suatu usaha manusia menyesuaikan diri dengan alam untuk memenuhi kebutuhan hidup mereka yang berkaitan dengan pengaturan dalam bidang-bidang ekonomi dalam rangka mencapai kehidupan yang sejahtera. Lembaga ekonomi bertujuan mengatur bidang-bidang ekonomi dalam rangka mencapai kehidupan yang sejahtera dan terpenuhinya kebutuhan masyarakat. Berdasarkan hasil wawancara dengan siswa SMP Negeri 4 Singaraja, siswa hanya mengetahui jenis lembaga ekonomi itu hanya bank saja, padahal disisi lain masih banyak terdapat lembaga ekonomi selain bank, misalnya saja LPD yang merupakan lembaga keuangan mikro yang dikelola oleh desa pakraman.

Salah satu keunikan di Bali adalah eksistensi dari desa pakraman dan desa. Lingkup desa pakraman tidak terbatas pada peran-peran sosial budaya dan keagamaan, melainkan juga ekonomi dan pelayanan umum yang umumnya berasal dari pemerintah. Melihat beratnya beban yang di pikul oleh desa pakraman, tentunya terbesit seberapa besar dana yang harus dikeluarkan oleh desa pakraman, tetapi ironisnya pembiayaan desa pakraman berada diluar kebijakan pembiayaan pemerintah. Kebijakan pembiayaan pemerintah hanya terbatas sampai desa saja, sedangkan desa pakraman juga memerlukan biaya yang tidak sedikit. Karena itu desa pakraman dituntut untuk memiliki tata kelola perekonomian mandiri, maka pada tahun 1984 pemerintah Bali mencetuskan pendirian Lembaga Perkreditan Desa diseluruh desa pakraman di Bali. Pada tahun 1984 dengan Surat Keputusan (SK) Gubernur No. 972 Tahun 1984 tentang Pendirian Lembaga Perkreditan Desa di Provinsi Daerah Tingkat I Bali. Proyek pendirian LPD mulai 
dilakukan dan keberadaan LPD diatur dibawah Peraturan Daerah (PERDA) yakni Peraturan Daerah Provinsi Bali Nomor 8 Tahun 2002 Tentang Lembaga Perkreditan Desa (LPD), yang kini telah diganti menjadi Peraturan Daerah Provinsi Bali Nomor 3 Tahun 2007. Perda tersebut mengatur mengenai syarat-syarat pendirian LPD. LPD sebagai suatu lembaga yang didirikan khusus untuk kepentingan demi mensejahterakan masyarakat desa pakraman, dalam kegiatannya hanya melayani masyarakat desa pakraman saja, LPD tidak melayani masyarakat diluar dari wilayah desa pakraman tempat LPD tersebut beroperasi. Karena itu LPD dikatakan sebagai lembaga ekonomi yang memiliki sifat khusus.

Dilihat dari LPD Sambangan yang lokasinya tidak terlalu jauh dari SMPN 4 Singaraja sebenarnya sangat cocok dijadikan sumber belajar IPS karena LPD Sambangan sendiri memiliki keunggulan dalam bidang kepemilikan asset sekitar 1,6 Miliar Rupiah pada tahun 2020 dimana LPD Sambangan bisa meningkatkan asetnya dalam mengelola LPD dalam kurun waktu 2 tahun yang pada tahun 2018 LPD ini kembali beroperasional selain itu LPD Sambangan juga memiliki keunggulan dalam penerapan awig-awig dan perarem yang dilaksanakan setiap satu Tahun sekali. Dari keunggulan dan kelebihan dari LPD Sambangan ini peneliti mengintegrasikan peranan LPD ke ranah pendidikan IPS yang nantinya dapat bermanfaat bagi pengetahuan siswa maupun siswi mengenai masalah sosial terkait dengan peranan LPD. Sumber Pembelajaran IPS beraneka ragam jenisnya, jadi disini bagaimana seorang guru bisa menempatkan objek atau subjek yang bisa dikaitkan dengan IPS bisa dijadikan suatu ilmu yang berguna bagi siswa maupun siswi.

Dalam melaksanakan penelitian, objek yang dipilih adalah LPD Desa Sambangan yang terletak di Desa Sambangan, Kecamatan Sukasada, Buleleng. Objek penelitian adalah sesuatu yang menjadi pemusatan pada kegiatan penelitian, atau dengan kata lain segala sesuatu yang menjadi sasaran penelitian (Sugiyono, 2002). Alasan pemilihan LPD Desa Sambangan sebagai objek penelitian adalah LPD Desa Sambangan merupakan LPD yang letaknya paling dekat dengan SMP Negeri 4 Singaraja, sehingga siswa bisa mengetahui LPD yang paling dekat dengan lingkungan sekolahnya. Sedangkan subjek penelitian yang digunakan adalah siswa kelas VII A1, VIII A1, dan IX A1 SMP Negeri 4 Singaraja. Subjek penelitian menurut Arikunto (2007) merupakan sesuatu yang sangat penting kedudukannya di dalam penelitian, subjek penelitian harus didata sebelum peneliti siap mengumpulkan data. Alasan dipilihnya SMP Negeri 4 Singaraja sebagai subjek penelitian adalah SMP Negeri 4 Singaraja merupakan sekolah unggulan yang mendapatkan prestasi/penghargaan Adi Wiyata Nasional Tahun 2017. Penggunaan Subyek penelitian yaitu SMP Negeri 4 Singaraja dalam penelitian ini karena terdapat berbagai perhitungan yang dijadikan alternatif, perhitungan dan pemilihan ini didasarkan atas daya dukung dan kompleksivitas yang dimiliki SMP Negeri 4 Singaraja sangat tinggi. Seperti dalam pembelajaran IPS di SMP Negeri 4 Singaraja yang menggunakan kurikulum 2013 sudah berpusat pada kearifan lokal sehingga bisa mengoptimalkan kemampuan belajar siswa.

Berdasarkan proses pembelajaran IPS yang telah dijabarkan di atas, penulis dapat menawarkan sebuah solusi bahan ajar IPS, yaitu LPD sebagai bahan ajar dalam pembelajaran IPS yang dapat diintegrasikan dalam materi kelas VII dalam kompetensi dasar mengidentifikasi interaksi sosial dalam ruang dan pengaruhnya terhadap kehidupan sosial, ekonomi, dan budaya dalam nilai dan norma serta kelembagaan sosial budaya. Dalam komptensi dasar ini terdapat materi mengenai Lembaga Sosial, dimana salah satu bagian dari Lembaga Sosial ini adalah Lembaga Ekonomi. Karena interaksi pada LPD memiliki karakter sebagai sumber pembelajaran IPS, seperti interaksi sosial (Sosiologi) dalam pengelolaan keuangan LPD dan pengelolaan dana masyarakat untuk kemajuan desa dikedepannya lagi (Ekonomi). Dalam pembelajaran IPS ini hanya akan dikaitkan dengan lingkungan hidup sekitar siswa dimana menggunakan LPD sebagai objek penelitian, diharapkan siswa lebih mengerti dan memahami bahwa dalam pembelajaran IPS memiliki sumber materi pembelajaran yang bersifat lokal, selain sebagai sumber materi yang bersifat lokal, siswa diharapkan memperoleh pendidikan nilai-nilai dalam fenomena sosial tersebut. 


\section{Metode}

Metode penelitian yang digunakan adalah metode penelitian yang bersifat Deskriptif Kualitatif dengan menekankan pada teknik-teknik pendekatan kualitatif. Menurut Sukmadinata (2009:94), penelitian kualitatif ditujukan untuk memahami fenomena-fenomena sosial dari sudut atau perspektif partisipan. Partisipan adalah orang-orang yang diajak wawancara, diobservasi, diminta memberikan data, pendapat, pemikiran, dan persepsinya. Penelitian kualitatif mengkaji perspektif partisipan dengan multi strategi, strategi-strategi yang bersifat interaktif, seperti observasi langsung, observasi partisipatif, wawancara mendalam, dokumen-dokumen, teknikteknik pelengkap seperti foto, rekaman, dan lain-lain.

Metode ini digunakan untuk mendukung penelitian yang mengkaji LPD Sambangan sebagai media sumber pembelajaran siswa SMP untuk kelas VII. Data penelitian ini dianalisis secara deskriptif kualitatif dan disajikan dalam bentuk naratif. Penelitian ini memaparkan makna, arti, dan fungsi dari data yang didapat oleh pelaku (informan). Penentuan tempat penelitian adalah di Desa Sambangan, Kecamatan Sukasada. Adapun lokasi ini dipilih karena disini peneliti menemukan bahwa pemahaman siswa dan siswi SMP N 4 Singaraja untuk kelas VII masih kurang memahami keberadaan dan peranan LPD sehingga karena lokasi ini berdekatan dengan SMP maka bisa dijadikan sampel didalam media pembelajaran IPS yang bertujuan untuk memantapkan pemahaman siswa terhadap keberadaan LPD.

Dalam pembelajaran IPS di SMP tersebut, khususnya pada kelas VII terdapat permasalahan dalam pembelajaran IPS seperti, siswa belum mengetahui adanya keberadaan LPD, buku paket yang materi didalamnya bersumber pada materi nasional, guru menggunakan model pembelajaran yang monoton, seperti tanya jawab, ceramah dan pembagian kelompok dan permasalahan terakhir dalam pembelajaran IPS adalah belum adanya pemahaman dari siswa tentang pembelajaran IPS yang bersumber materi lokal. Dari sinilah peneliti mempunyai inisiatif untuk menggunakan LPD Sambangan sebagai pengayaan materi pembelajaran IPS di Kelas VII.

\section{Hasil dan Pembahasan}

Lembaga Perkreditan Desa (LPD) Desa Adat Sambangan didirikan berdasarkan SK Gubernur Nomor 144 Tahun 1992 tanggal 26 Februari 1992. LPD Desa Adat Sambangan merupakan lembaga keuangan milik Desa Adat Sambangan. Potensi Desa Adat Sambangan terdiri dari tiga banjar adat dengan jumlah krama wed (penduduk asli) sebanyak 1.059 KK terdiri dari : (1) Banjar Adat Banjar Anyar $152 \mathrm{KK}$; (2) Banjar Adat Sambangan $368 \mathrm{KK}$; (3) Banjar Adat Babakan 539 KK. Sampai dengan periode bulan September 2020, jumlah krama desa yang telah terlayani LPD Desa Adat Sambangan sebanyak 905 orang (31 orang berupa nasabah Deposito, nasabah Tabungan sebanyak 751 orang, serta nasabah kredit sebanyak 123 orang). Melihat potensi wilayah dan jumlah penduduk maka belum semua krama adat terlayani oleh LPD.

Pada periode 31 Desember 2019, total kekayaan LPD Desa Adat Sambangan mencapai sebesar Rp. 1.619.883.918,24,-. Kekayaan ini bersumber dari modal disetor desa adat, tabungan masyarakat, deposito, dan bantuan dana perlindungan dari LPLPD Provinsi Bali. Pada periode 30 September 2020, kekayaan LPD Desa Adat Sambangan mencapai sebesar Rp. 2.048.722.515,36,atau mengalami peningkatan sebesar Rp. 428.838.597,12,- $(26,47 \%)$ bila dibandingkan dengan keadaan pada periode 31 Desember 2019. Peningkatan kekayaan LPD tersebut seiring ditambahnya modal dari cadangan umum, meningkatnya hutang LPD dari sektor tabungan masyarakat seperti tabungan sukarela dan deposito, pinjaman dana perlindungan dari LPLPD Provinsi, juga berasal dari pendapatan bunga pinjaman yang diberikan kepada nasabah. Tabungan masyarakat, modal dan pencapaian laba LPD dalam kurun waktu sembilan bulan mengalami peningkatan yang cukup baik. 
Lembaga Perkreditan Desa (LPD) sebagai salah satu lembaga keuangan milik Desa Adat telah menunjukkan peranannya dalam mendorong pembangunan ekonomi pedesaaan, menciptakan kesempatan berusaha dan peluang kerja bagi masyarakat desa serta berperan dalam menunjang sebagai salah satu lembaga keuangan mikro, LPD selama ini masih tetap eksis dan mampu bersaing dengan lembaga keuangan lainnya termasuk Bank.

Mode atau cara pengintegrasian materi yang dianggap sesuai dengan memanfaatkan berbagai sumber yang ada pada kehidupan siswa sehari-hari merupakan salah satu inovasi untuk mengembangkan pembelajaran IPS, salah satunya adalah LPD yang merupakan Lembaga keuangan tradisional yang ada disekitar lingkungan siswa. Alasan utama dipilihnya LPD sebagai sumber belajar siswa adalah berdasarkan permasalahan-permasalahan pembelajaran IPS yang makin hari maki mengalami problematika yang berkepanjangan. Sesuai dengan hasil observasi dokumen silabus, Standar kompetensi dan kompetensi dasar serta lingkup materi ajar, Selanjutnya, potensi LPD Sambangan berpotensi dijadikan dasar pengembangan Sumber belajar dalam bentuk handout materi dan RPP.

Lewat proses belajar mengajar, diharapkan dapat mengkaji potensi yang ada di lingkungan siswa, seperti nilai kearifan karakter dalam pengintegrasian LPD Sambangan, sehingga siswa atau peserta didik dapat lebih memahami kondisi daerah atau lngkungannya sekaligus memahami nilai nilai kearifan lokal, berkaitan upaya pencapaian kompetensi dasar pada mata pelajaran IPS. Pengintegrasian dilaksanakan dengan memanfaatkan potensi utama LPD sebagai Lembaga keuangan tradisional, dijadikan sebagai sumber belajar mengingat banyak nilai-nilai yang perlu dipelajari dan diwariskan pada generasi muda atau pelajar berupa nilai-nilai kearifan lokal dan nilai Pendidikan karakter. (Mantaka, 2017).

Pengintegrasian LPD Sambangan dalam pembelajaran IPS di SMPN 4 Singaraja merupakan upaya untuk mengembangkan pembelajaran IPS dengan inovasi pembelajaran bisa berlangsung lebih baik, inovatif, karena pembelajaran yang ditampilkan berwawasan lingkungan yang akan menjadikan pembelajaran lebih bermakna karena akan bermanpaat bagi siswa dalam kehidupannya di masyarakat. Pengintegrasian dalam pembelajaran merupaka upaya pelestarian nilai-nilai kearifan lokal dan pendidikan karakter, yang perlu dilakukan agar siswa mampu mengenal lingkungan dan daerah dimana ia berada, sehingga dapat mengambil nilai-nilai kearifan lokal itu dalam kehidupan nyata dan memanfaatkannya.

Pengintegrasian LPD Sambangan sebagai Lembaga Ekonomi merupakan cerminan inovasi dari pembelajaran IPS sangat relevan dijadikan sebagai media pembelajaran Ilmu Pengetahuan Sosial (IPS) kelas VII semester ganjil di Sekolah Menengah Pertama (SMP) yakni pada materi Pengertian, Jenis, dan Fungsi Lembaga Sosial dan lebih tepatnya pada Kompetensi Dasar (KD) mengidentifikasi interaksi sosial dalam ruang dan pengaruhnya terhadap kehidupan sosial, ekonomi, dan budaya dalam nilai dan norma serta kelembagaan sosial budaya. Adapun nilai-nilai karakter yang terkandung dalam Pengintegrasian LPD Desa Sambangan dalam pembelajaran IPS yaitu, religius, disiplin, gotong royong, kejujuran, tanggung jawab, dan kerja keras. Selain itu dalam pengintegrasian LPD kedalam pembelajaran IPS, LPD Sambangan memiliki nilai unik yang dijadikan sebagai dasar dalam penelitian ini seperti: Nilai Taksu, Tri Hita Karana, Menyama Braya dan Jengah.

Suhartini (2009) menyatakan bahwa kearifan lokal ikut berperan dalam pengelolaan sumber daya alam dan lingkungannya. Kearifan lokal berkembang dimasyarakat pedesaan merupakan hasil dari kebiasaan masyarakat setempat atau kebudayaan masyarakat sebagai bentuk adaptasi terhadap alam dan lingkungan tempat tinggalnya. Masyarakat menggunakan cara-cara tersendiri untuk mengelola alam dan lingkungan. Kebiasaan-kebiasaan itu kemudian membentuk dengan apa yang disebut dengan kearifan lokal. Kearifan lokal mengandung nilai, kepercayaan, dan sistem religi yang dianut masyarakat setempat. Kearifan lokal pada intinya 
kegiatan yang melindungi dan melestarikan alam dan lingkungan. Oleh karena itu, penting untuk mengkaji dan melestarikan kearifan lokal yang berkembang di masyarakat.

Namun seiring berjalannya waktu keberadaan kearifan lokal semakin tersingkirkan dengan masuknya berbagai teknologi dan berbagai masalah sosial yang dihadapi masyarakat seperti pertambahan penduduk yang semakin meningkat. Keadaan demikian membuat masyarakat meninggalkan kearifan lokal yang telah diturunkan secara turun-menurun. Pola pikir masyarakat mulai berubah seiring dengan memudarnya kearifan lokal yakni dari pola piker holistik ke pola pikir mekanik. Masyarakat tidak lagi memikirkan keseimbangan alam dalam suatu lingkungan tempat tinggal. Di tengah arus globalisasi tersebut, fenomena yang terjadi membuat semakin menipisnya pemahaman peserta didik baik dalam jenjang sekolah dasar sampai menengah atas tentang sejarah lokal serta tradisi budaya yang ada dalam masyarakat. Oleh karena itu alangkah lebih baiknya jika lembaga pendidikan mampu menciptakan kegiatan pendidikan yang mengupayakan bagaimana caranya agar aneka ragam budaya yang telah dimiliki bangsa yang besar ini bisa dijaga dan dilestarikan bersama-sama.

Pendidikan di Indonesia membutuhkan pendidikan yang membentuk karakter peserta didiknya sesuai dengan karakter yang telah diwariskan oleh budaya lokal yang telah ada sejak zaman dahulu. Maka dari itu, Lembaga pendidikan di Indonesia dapat menerapkan pendidikan yang berbasis pada local wisdom (kearifan lokal). Kearifan lokal merupakan produk budaya masa lalu yang patut secara terus-menerus dijadikan pegangan hidup. Meskipun bernilai lokal tetapi nilai yang terkandung didalamnya sangat universal.

Hasil pemantauan menunjukan bahwa sebagian besar guru-guru masih belum paham benar akan pembelajaran yang berbasis kompetensi dan pembelajaran melalui pendekatan konstektual, baik konsep maupun penerapannya. Kondisi demikian dipengaruhi oleh beberapa faktor-faktor antara lain, terbatasnya rujukan atau bahan pustaka yang sesuai dengan kebutuhan guru, rendahnya kemauan sebagian besar besar untuk meningkatkan pengetahuan akademis dan profesionalnya, dan kurang terpadunya pembinaan guru oleh lembaga-lembaga terkait (Muslich, 2009).

Dengan menerapkan pendidikan berbasis pada kearifan lokal maka peserta didik diharapkan akan mampu menciptakan pendidikan yang memberi makna bagi kehidupan manusia Indonesia, Artinya pendidikan mampu menciptakan generasi-generasi muda yang mampu melestarikan dan mencintai budaya sendiri. Selain itu, pendidikan harus mampu membentuk karakter manusia yang berintegritas tinggi dan berkarakter sehingga mampu melahirkan tunastunas bangsa yang hebat dan bermartabat sesuai dengan spirit pendidikan yaitu memanusiakan manusia.

Prospek kearifan lokal sangat bergantung kepada bagaimana masyarakat melestarikan kembali kearifan lokal yang ada dan bagaimana masyarakat mengubah pola pikirnya kembali ke pola holistik. Sehingga sumber daya alam dan lingkungan alam yang dimiliki masyarakat dapat dimanfaatkan dan dilestarikan dengan tanpa mengganggu keseimbangannya. Dampak pengintegrasian LPD Sambangan sebagai lembaga ekonomi terhadap pembelajaran IPS dikelas VII SMP N 4 Singaraja berbasis kearifan lokal adalah adanya nilai-nilai karakter yang dapat dipetik dari adanya LPD Sambangan yang merupakan salah satu lembaga keuangan yang kini peranannya dan keberadaanya masih sangat sedikit mengetahui.

Nilai-nilai karakter dari LPD Sambangan sebagai lembaga ekonomi tradisional di Desa Sambangan dapat dijadikan sebagai pembelajaran IPS berbasis kearifan lokal di SMP adalah diimplementasikan melalui pendidikan karakter yang memuat nilai-nilai yang perlu ditanamkan, ditumbuhkan dan dikembangkan kepada setiap peserta didik. Nilai-nilai yang dikembangkan tersebut tidak lepas dari budaya bangsa. Budaya bangsa merupakan sistem nilai yang dihayati, diartikan sebagai keseluruhan sistem berpikir tentang tata nilai, moral, norma dan keyakinan manusia yang dihasilkan masyarakat (Darmayanti, 2014: 42) 
Dari hasil observasi dan wawancara dapat diambil simpulan yakni dalam pengintegrasian LPD Sambangan dalam pembelajaran IPS di SMP N 4 Singaraja terdapat nilai-nilai karakter yang dapat kita jadikan cerminan dalam bertindak dan patut diteladani antara lain religius, disiplin, gotong royong/kerja sama, kejujuran, tanggung jawab, dan kerja keras. Nilai kearifan lokal yang terdapat pada LPD Sambangan yakni Taksu, Tri Hita Karana, Menyama Braya dan Jengah.

RPP yang dapat dikembangkan lagi oleh guru IPS mengacu pada Peraturan Menteri Pendidikan dan Kebudayaan Republik Indonesia Nomor 14 Tahun 2019 tentang penyederhanaan rencana pelaksanaan pembelajaran yang dimana dalam Peraturan Menteri tersebut ditekankan penyusunan rencana pelaksanaan pembelajaran dilakukan dengan prinsip efisien, efektif, dan berorientasi pada murid. Mengenai penggunaan rencana pelaksanaan pembelajaran daring (dalam jaringan) mengacu pada Surat Edaran Nomor 15 Tahun 2020 Kemdikbud tentang Penyelenggaraan Pembelajaran dari Rumah dalam Masa Darurat Penyebaran Covid-19.

Pada dasarnya masih banyak sumber materi yang dapat dijadikan bahan dalam memberikan pengayaaan pada pembelajaran IPS, bukan hanya bertumpu pada sektor LPD sebagai Lembaga ekonomi saja, melainkan juga aktivitas sosial berupa organisasi tradisional seperti subak maupun informal yang ada dilingkungan Desa Sambangan yang dapat dijadikan sumber materi untuk pengayaan dalam pembelajaran IPS. Semuanya kembali lagi kepada pengemasan materi untuk pengayaan dalam pembelajaran IPS yang dapat dipadukan dengan berbagai metode inovatif lainnya.

Dengan menariknya pembelajaran dan bertambahnya wawasan siswa terhadap lingkungan sekitar, diharapkan tujuan dari pendidikan IPS yang berupaya melahirkan peserta didik yang bukan hanya berkarakter dan berakhlak mulia, tetapi juga melahirkan peserta didik yang memiliki jati diri dan mencintai kekayaan daerahnya yang sedari awal dikenalkan melalui pembelajaran IPS berbasis masyarakat yang bermuatan dengan pembelajaran nilai.

Sugihartono, dkk (2007: 8) mengemukakan bahwa persepsi adalah kemampuan otak dalam menerjemahkan stimulus atau proses untuk menerjemahkan stimulus yang masuk ke dalam alat indera manusia. Persepsi manusia terdapat perbedaan sudut pandang dalam penginderaan. Ada yang mempersepsikan sesuatu itu baik atau persepsi yang positif maupun persepsi negatif yang akan mempengaruhi tindakan manusia yang tampak atau nyata. Bimo Walgito (2004: 70) mengungkapkan bahwa persepsi merupakan suatu proses pengorganisasian, penginterpretasian terhadap stimulus yang diterima oleh organisme atau individu sehingga menjadi sesuatu yang berarti, dan merupakan aktivitas yang integrated dalam diri individu. Respon sebagai akibat dari persepsi dapat diambil oleh individu dengan berbagai macam bentuk. Stimulus mana yang akan mendapatkan respon dari individu tergantung pada perhatian individu yang bersangkutan. Berdasarkan hal tersebut, perasaan, kemampuan berfikir, pengalaman-pengalaman yang dimiliki individu tidak sama, maka dalam mempersepsi sesuatu stimulus, hasil persepsi mungkin akan berbeda antar individu satu dengan individu lain.

Pengintegrasi LPD Sambangan ke dalam pembelajaran IPS memberikan persepsi dari siswa maupun guru IPS di SMP N 4 Singaraja, hal ini tidak terlepas dari permasalahan mendasar pendidikan IPS di sekolah yang diungkapkan oleh Solihatin (2012), yaitu (1) masih menggunakan model pembelajaran konvensional, (2) tujuan pendidikan IPS sulit dicapai, (3) siswa menjadi objek pembelajaran, (4) teacher centre, (5) kurang mendorong dan merangsang siswa untuk mengembangkan potensi inkuiri, (6) materi IPS masih bersifat hafalan, (7) evaluasi hanya sebatas pada kognitif, (8) prestasi siswa tidak dioptimalkan, dan (9) pola interaksi dalam pembelajaran masih bersifat satu arah. Kelemahan pendidikan IPS yang berkaitan dengan pembahasan ini adalah bersumber dari Susanto (2014), Pendidikan IPS dikatakan tidak bisa memberikan makna dari apa yang telah dipelajari, sehingga dianggap hanya untuk kepentingan sesaat tanpa ada manfaat praktis dalam kehidupan sehari-hari di masyarakat dan belum menjadikan nilai sosial budaya yang dikembangkan di lingkungan masyarakat menjadi sumber belajar siswa. 
Mengingat persoalan-persoalan yang terjadi sangat krusial dalam peroses tersebut, sehingga dibutuhkan upaya dan mesinergitaskan yang cerdas untuk menjawab semua bentuk persoalan yang ada terutama pengembangan pendidikan karakter dalam pendidikan IPS. Pemanfaatan lingkungan sekitar sekolah dan siswa sebagai sumber utama materi pengayaan dalam pembelajaran IPS merupakan sebuah kewajiban, mengingat laboratorium IPS adalah masyarakat, lingkungan, dan interaksinya (Lasmawan, 2010). Bertalian dengan itu, maka salah satu yang dianggap layak untuk dijadikan sumber belajar khususnya pendidikan karakter adalah LPD yang merupakan salah satu lembaga ekonomi.

Hasil wawancara dengan guru IPS dan siswa-siswi kelas VII di SMPN 4 Singaraja mengenai persepsi tentang pengintegrasian LPD Sambangan ke dalam pembelajaran IPS dapat disimpulkan bahwa persepsi guru dan siswa berbanding lurus dengan apa yang dituangkan peneliti yaitu mereka setuju dan mendukung penyisipan bahan ajar LPD Sambangan kedalam pembelajaran IPS. Penyisipan materi ini tidak terlepas dari keterbatasan materi yang ada dibeberapa literatur dan bahan ajar IPS. Adanya penyisipan ini secara langsung akan berdampak terhadap proses pembelajaran IPS karena adanya inovasi dan pembaharuan IPS yang dilakukan guru.

\section{Simpulan dan Saran}

Sejarah berdirinya Lembaga Perkreditan Desa (LPD) Desa Adat Sambangan adalah didirikan berdasarkan SK Gubernur Nomor : 144 Tahun 1992 tanggal 26 Februari 1992. LPD Desa Adat Sambangan merupakan lembaga keuangan milik Desa Adat Sambangan. Potensi Desa Adat Sambangan terdiri dari tiga banjar adat dengan jumlah krama wed (penduduk asli) sebanyak 1.059 KK terdiri dari : (1) Banjar Adat Banjar Anyar $152 \mathrm{KK}$; (2) Banjar Adat Sambangan 368 KK ; (3) Banjar Adat Babakan 539 KK. Sampai dengan periode bulan September 2020, jumlah krama desa yang telah terlayani LPD Desa Adat Sambangan sebanyak 905 orang (31 orang berupa nasabah Deposito, nasabah Tabungan sebanyak 751 orang, serta nasabah kredit sebanyak 123 orang).

Inovasi pembelajaran sangat penting dilakukan pada semua mata pelajaran, melainkan bukan hanya mata pelajaran IPS saja mengingat fungsi utama dari penginovasian pembelajaran adalah untuk meningkatkan minat belajar pada pelajaran yang di inovasi melalui penggunaan sumber belajar yang ada pada sekitar kehidupan atau lingkungan siswa. Inovasi juga berperan penting dalam peningkatan pengamalan dan implementansi pada materi yang bisa diwujudkan dengan kegiatan nyata dalam menghadapi suatu permasalah yang dihadapi peserta didik.

Nilai-nilai karakter pada LPD Sambangan yang dapat diintegrasikan dalam pembelajaran IPS, berpedoman pada 18 nilai-nilai karakter yang direkomendasikan oleh Kemendiknas (2010). Pembelajaran dengan menintegrasikan pendidikan karakter memang semakin diutamakan akhirakhir ini, LPD Sambangan mampu merepresentasikan sebagian nilai-nilai karakter yang berpedoman pada Kemendiknas (2010). Hasil penelitian menunjukkan terdapat 6 nilai karakter dari 18 nilai karakter Kemendiknas yang tercermin dan terepresentasikan pada LPD Sambangan yaitu Religius, Disiplin, Gotong Royong atau Kerja Sama, Kejujuran, Tanggung Jawab, dan Kerja Keras. Dengan demikian, pemanfaatannya sebagai pemgembangan pembelajaran nilai-nilai karakter khususnya pada pembelajaran IPS sangat layak untuk diterapkan. Selain 18 Nilai karakter dapat dipresentasikan dalam LPD Sambangan terdapat pula nilai kearifan lokal seperti Taksu, Tri Hita Karana, Menyama Braya, dan Jengah.

RPP yang dikembangkan dalam mengintegrasikan LPD Sambangan ke dalam pembelajaran IPS adalah mengacu pada Peraturan Menteri Pendidikan dan Kebudayaan Republik Indonesia Nomor 14 Tahun 2019 tentang penyederhanaan rencana pelaksanaan pembelajaran yang dimana dalam Peraturan Menteri tersebut ditekankan penyusunan rencana pelaksanaan pembelajaran dilakukan dengan prinsip efisien, efektif, dan berorientasi pada murid. Mengenai penggunaan 
rencana pelaksanaan pembelajaran daring (dalam jaringan) mengacu pada Surat Edaran Nomor 15 Tahun 2020 Kemdikbud tentang Penyelenggaraan Pembelajaran dari Rumah dalam Masa Darurat Penyebaran Covid-19.

Persepsi tentang pengintegrasian LPD Sambangan ke dalam pembelajaran IPS dapat disimpulkan bahwa persepsi guru dan siswa berbanding lurus dengan apa yang dituangkan peneliti yaitu mereka setuju dan mendukung penyisipan bahan ajar LPD Sambangan ke dalam pembelajaran IPS. Penyisipan materi ini tidak terlepas dari keterbatasan materi yang ada dibeberapa literatur dan bahan ajar IPS. Adanya penyisipan ini secara langsung akan berdampak terhadap proses pembelajaran IPS karena adanya inovasi dan pembaharuan IPS yang dilakukan guru.

Dengan adanya pengintegrasian ini, maka guru kreatif dan inovatiflah yang dibutuhkan dalam mengajarkan pelajaran IPS, guru yang peka dengan lingkungan sekitar, dapat mengaplikasikan model pembelajaran inovatif, serta mengajak siswa tidak hanya berfikir tetapi menghayati dan memaknai sebuah peristiwa merupakan sosok guru yang kiranya dapat membenahi image pembelajaran IPS yang selama ini dikenal sebagai mata pelajaran yang membosankan dan bersifat hafalan.

\section{Daftar Pustaka}

Al Muchtar, S. (2001). Pendidikan dan Masalah Sosial Budaya. Bandung: Gelar Pustaka Mandiri.

Arikunto, S. (2007). Prosedur Penelitian Suatu Pendekatan Praktek Edisi Revisi VI. Jakarta: Rineka Apta.

Darmayanti, D. (2014). Panduan Implementasi Pendidikan Karakter di Sekolah. Yogyakarta: Araska.

Kementerian Pendidikan Nasional. 2010. Direktorat Jenderal Manajemen Pendidikan Dasar dan Menengah, Direktorat Pembinaan Sekolah Menengah Pertama, Panduan Pendidikan Karakter di Sekolah Menengah Pertama. Jakarta: Kementerian Pendidikan Nasional.

Lasmawan, W. (2010). Pendidikan IPS Dalam Perspektif Kontekstual-Empiris. Singaraja: Mediakom Indonesia Press Bali.

Mantaka. (2017). Pengintegrasian Kearifan Lokal Subak Abian Catu Desa Sambirenteng Buleleng Bali Sebagai Sumber Belajar IPS di SMP. Jurnal Pendidikan IPS Indonesia, 1(2).

Muslich, M. (2009). KTSP: Pembelajaran Berbasis Kompetensi dan Kontekstual. Cetakan 5. Jakarta: PT Bumi Aksara.

Pemerintah Provinsi Bali. 1992. Peraturan Gubernur Bali Nomor 144 Tahun 1992 tentang Pendirian Lembaga Perkreditan Desa

Peraturan Daerah Provinsi Bali Nomor 3 Tahun 2007 Tentang Perubahan Atas Peraturan Daerah Provinsi Bali Nomor 8 Tahun 2002 Tentang Lembaga Perkreditan Desa.

Republik Indonesia. 2019. Peraturan Menteri Pendidikan dan Kebudayaan Republik Indonesia Nomor 14 Tahun 2019 tentang penyederhanaan rencana pelaksanaan pembelajaran.

Republik Indonesia. 2020. Surat Edaran Nomor 15 Tahun 2020 Kemdikbud tentang Penyelenggaraan Pembelajaran dari Rumah dalam Masa Darurat Penyebaran Covid-19.

Solihatin, E. (2012). Strategi Pembelajaran PPKN. Jakarta: Bumi Aksara.

Sugihartono. (2007). Psikologi Pendidikan. Yogyakarta: UNY Pers.

Sugiyono. (2002). Metode Penelitian Administrasi. Bandung: CVAlfabet.

Suhartini. (2009). Kajian Kearifan Lokal Masyarakat dalam Pengelolaan Sumberdaya Alam dan Lingkungan. Tersedia pada :http://staff.uny.ac.id. Diakses pada tanggal 23 Maret 2021.

Sukmadinata, N. S. (2009). Metode Penelitian Pendidikan. Bandung: PT Remaja Rosdakarya.

Susanto, A. (2014). Teori Belajar dan Pembelajaran di Sekolah Dasar. (Jakarta: Kencana Prenada Media Group).

Walgito, B. (2004). Pengantar Psikologi Umum. Jakarta: Penerbit Andi. 